\title{
Faktor yang Memengaruhi Auditor Switching di Indonesia
}

\author{
Retna Safriliana \\ Siti Muawanah \\ Universitas Merdeka Malang, \\ Jalan Terusan Dieng No 62-64, Kota Malang, Indonesia, 65146 \\ retnasafriliana@yahoo.com
}

\begin{abstract}
The purposes of this research are to examine the effect of audit opinion, public accounting firm size, financial distress and audit committee on auditor switching. This research is qualified as a confirmation research. Auditor switching is a change of public accountant firms at a certain time as stipulated by Regulation of the Ministry of Finance No.17/PMK.01/2008 concerning Public Accounting Services which has been revised to No.KEP-86/BL/2011, that the provision of Public Audit services for six consecutive years by Public Accounting Firm and three consecutive years by a public accountant with one client. The research sample is selected with random sampling method and includes 300 data, taken from 50 manufacturing companies listed in Indonesia Stock Exchange in 2011-2016. Logistic regression is used for analysing the data, and auditor switching is measured by dummy variables. The results of this study show that public accounting firm size and audit committee affect the auditor switching, while the audit opinion and financial distress does not affect the auditor switching.
\end{abstract}

Keywords: Auditor Switching, Audit Opinion, Public Accountant Firm Size, Financial Distress

\begin{abstract}
Abstrak
Tujuan dari penelitian ini adalah untuk menguji dampak dari opini audit, ukuran kantor akuntan publik, financial distress dan komite audit pada auditor switching. Penelitian ini tergolong dalam penelitian konfirmatori. Auditor switching adalah pergantian dari Kantor Akuntan Publik pada waktu tertentu sebagaimana ditetapkan oleh Surat Keputusan Menteri Keuangan No.17/PMK.01/2008 tentang Jasa Akuntan Publik yang telah direvisi menjadi No.KEP-86/BL/2011, yang memberikan jasa Audit Publik selama enam tahun berturut-turut oleh KAP dan tiga tahun berturut-turut oleh satu akuntan publik dengan klien yang sama. Sampel penelitian dipilih dengan cara acak dan berjumlah 300 data, yang diambil dari 50 perusahaan manufaktur di Bursa Efek Indonesia di tahun 2011-2016. Alat analisis data yang digunakan adalah Regresi Logit, dan auditor switching diukur dengan menggunakan variabel dummy. Hasil dari studi ini menunjukkan bahwa ukuran KAP dan komite audit mempengaruhi auditor switching, disamping itu opini audit dan financial distress tidak mempengaruhi auditor switching.
\end{abstract}

Kata Kunci: Auditor Switching, Opini Audit, Ukuran KAP, Financial Distress

\section{PENDAHULUAN}

Auditor switching merupakan pergantian Kantor Akuntan Publik (KAP) yang dilakukan perusahaan baik dengan kemauan sendiri atau karena peraturan pemerintah. Auditor switching secara mandatori telah diatur pemerintah melalui Surat Keputusan Menteri Keuangan No.17/PMK.01/2008 tentang Jasa Akuntan Publik yang telah direvisi menjadi No.KEP-86/BL/2011 yang berlaku sejak tanggal 28 Februari 2011. Pasal 3 ayat 1 tentang pemberian jasa audit umum dalam peraturan tersebut menyebutkan bahwa auditor dapat memberikan jasanya selama enam tahun berturut-turut oleh KAP dan tiga tahun berturut- turut oleh akuntan publik yang sama. Lebih lanjut, pasal 3 ayat 2 menyatakan bahwa Akuntan Publik dan KAP boleh menerima kembali penugasan setelah satu tahun buku tidak memberikan jasa audit kepada klien yang sama.

Perusahaan yang menggunakan KAP dalam jangka waktu lama menimbulkan hubungan kekeluargaan antara keduanya, sehingga dapat menurunkan kualitas audit. Pembatasan jangka waktu perikatan menyebabkan terbatasnya masa keterikatan sehingga terjadi auditor switching. Auditor switching secara sukarela dilakukan ketika tidak ada peraturan yang mewajibkannya (Susan dan Trisnawati, 2011). Auditor switching menjadi penting untuk diteliti karena pergantian auditor yang dilakukan oleh perusahaan merupakan bentuk kredibilitas pelaporan keuangan. 
Efendy dan Rahayu (2015) menyatakan bahwa opini audit tidak berpengaruh signifikan terhadap auditor switching. Faktor lain yang berpengaruh terhadap auditor switching adalah Ukuran KAP. Ukuran KAP berpengaruh negatif terhadap auditor switching. Semakin besar ukuran KAP, semakin rendah kemungkinan terjadinya auditor switching. Meskipun demikian, Susan dan Trisnawati (2011) menyebutkan bahwa ukuran KAP berpengaruh positif terhadap auditor switching. Auditor switching juga bisa disebabkan oleh kebijakan perusahaan untuk menjaga stabilitas finansial (Salim dan Rahayu, 2014). Berbeda dengan Salim dan Rahayu (2014), Budiono (2015), serta Wea dan Murdiati (2015) menyebutkan bahwa financial distress tidak berpengaruh terhadap auditor switching. Komite Audit melaksanakan tugasnya secara mandiri dan independen. Independensi komite audit berpengaruh terhadap auditor switching. Hasil penelitian yang tidak konsisten antara satu penelitian dengan penelitian yang lain menarik untuk diteliti kembali. Oleh karena itu, penelitian ini bertujuan untuk menguji pengaruh opini audit, ukuran KAP, financial distress, dan komite audit terhadap auditor switching.

\section{Landasan Teori}

Teori Agensi merupakan teori yang menjelaskan hubungan kontraktual antara principal dan agents. Pihak principal (pemegang saham) adalah pihak yang memberikan mandat kepada agent (manajer) untuk melakukan kegiatan atas nama prinsipal dengan kapasitas sebagai pengambil keputusan (Jansen danMeckling, 1979). Pada saat pemegang saham menunjuk manajer sebagai pengelola dan pengambil keputusan bagi perusahaan, maka muncul hubungan keagenan antara keduanya. Manajer mengemban tanggung jawab moral untuk mengoptimalkan kepentingan pemegang saham. Auditor merupakan pihak yang berfungsi untuk menjembatani perbedaan kepentingan tersebut. Auditor melakukan fungsi pengawasan terhadap manajer melalui pemeriksaan laporan keuangan tahunan. Tugas Auditor adalah memastikan bahwa laporan keuangan telah disajikan secara wajar sesuai dengan standar yang berlaku.

Dukungan terhadap profesionalisme auditor dilakukan oleh pemerintah melalui pembuatan peraturan terkait. Hal itu dilakukan untuk mendukung perekonomian yang sehat dan efisien. Pengaturan, pembinaan, dan pengawasan yang efektif dan berkesinambungan terus dilakukan oleh pemerintah dengan penerbitan Keputusan Menteri Keuangan Nomor 423/KMK.06/2002 tentang Jasa Akuntan Publik yang telah diubah dengan Keputusan Menteri Keuangan Nomor 359/KMK.06/2003. Pada tahun 2008 peraturan tersebut diubah kembali melalui pengesahan Peraturan Menteri Keuangan Nomor: 17/PMK.01/2008 tentang Jasa Akuntan Publik. Peraturan tersebut mengharuskan perusahaan untuk mengganti auditor dan KAP pada periode yang telah di tentukan. Auditor switching merupakan pergantian KAP yang dilakukan oleh perusahaan karena peraturan pemerintah (mandatory) atau keinginan perusahaan sendiri (voluntary). Mandatory apabila perusahaan melakukan pergantian auditor sesuai dengan kewajiban yang telah diatur dalam Peraturan Menteri Keuangan Nomor 17/PMK.01/2008. Voluntary apabila perusahaan melakukan pergantian auditor tidak berdasarkan peraturan rotasi auditor.

\section{Pengaruh Opini Audit terhadap Auditor Switching}

Opini Audit adalah pernyataan auditor terhadap kewajaran laporan keuangan atas hasil audit entitas. Kewajaran ini menyangkut materialitas salah saji dalam posisi keuangan, hasil usaha dan arus kas. Opini dalam laporan audit sangat penting bagi para pemakai laporan keuangan. Opini audit merupakan kesimpulan penilaian auditor atas kewajaran laporan entitas (Aurora, 2013). Penelitian Salim dan Rahayu, (2014) menunjukkan bahwa opini audit tidak memiliki pengaruh terhadap auditor switching, namun ketika dimodifikasi dengan opini audit going concern terdapat pengaruh opini audit terhadap auditor switching. Efendy dan Rahayu (2015) mengatakan bahwa opini audit tidak berpengaruh terhadap auditor switching. Oleh karena itu, dapat dirumuskan hipotesis sebagai berikut.

$\mathrm{H}_{1}$ : Opini audit berpengaruh positif terhadap auditor switching 


\section{Pengaruh Ukuran KAP terhadap Auditor Switching}

Kualitas audit di Indonesia, sering dikaitkan dengan afiliasi asing yang dimiliki. KAP yang memiliki afiliasi dengan KAP asing memiliki kualitas audit yang lebih tinggi dibandingkan KAP yang tidak berafiliasi asing. KAP besar dan KAP kecil memiliki kemampuan dan sumber daya yang sangat berbeda, sehingga alasan pemutusan perikatan audit dapat berbeda pula. Empat KAP besar yang ada di Indonesia adalah Deloitte Touche Tohmatsu (Deloitte) yang berafiliasi dengan Osman Bing Satrio \& Rekan, Ernst \& Young (EY) yang berafiliasi dengan Purwantoro, Suherman \& Surja, Klynveld Peat Marwick Goaerdeler (KPMG) yang berafiliasi dengan Siddharta \& Widjaja, serta PricewaterhouseCooper (PWC) yang berafiliasi dengan Tanudiredja, Wibisana \& Rekan. Efendi dan Rahayu (2015) menyebutkan bahwa ukuran KAP berpengaruh negatif terhadap auditor switching, sedangkan menurut Susan dan Trisnawati (2011) ukuran KAP berpengaruh positif terhadap auditor switching. Oleh karena itu, dapat dirumuskan hipotesis sebagai berikut.

$\mathrm{H}_{2}$ : Ukuran KAP berpengaruh positif terhadap auditor switching

\section{Pengaruh Financial Distress terhadap Auditor Switching}

Financial distress berarti kesulitan dana untuk menutup kewajiban perusahaan atau kesulitan likuiditas yang diawali dengan kesulitan ringan sampai pada kesulitan yang lebih serius, yaitu jika utang lebih besar dibandingkan dengan aset. Definisi financial distress yang lebih pasti sulit dirumuskan tetapi terjadi dari kesulitan ringan sampai berat. Penelitian sebelumnya tentang pengaruh financial distress terhadap auditor switching menunjukkan hasil yang tidak konsisten. Salim (2014) menyebutkan bahwa financial distress memiliki pengaruh signifikan terhadap auditor switching, namun menurut Budiono (2015) financial distress tidak berpengaruh signifikan terhadap auditor switching. Oleh karena itu, dapat dirumuskan hipotesis sebagai berikut.

$\mathrm{H}_{3}$ : Financial distress berpengaruh positif terhadap auditor switching.

\section{Pengaruh Komite Audit terhadap Auditor Switching}

Komite Audit adalah sekelompok orang yang dipilih oleh kelompok yang lebih besar untuk mengerjakan pekerjaan tertentu atau untuk melakukan tugas-tugas khusus atau sejumlah anggota dewan komisaris perusahaan klien yang bertanggungjawab untuk membantu auditor dalam mempertahankan independensinya dari manajemen. Penelitian sebelumnya menunjukkan hasil yang tidak konsiten tentang pengaruh komite audit terhadap auditor switching, penelitian Pratiwi dan Latrini (2015) menyatakan bahwa aktivitas komite audit yang diukur dengan frekuensi pertemuan yang dilakukan oleh komite audit tidak mampu memoderasi penerbitan opini going concern pada auditor switching. Oleh karena itu, dapat dirumuskan hipotesis sebagai berikut.

$\mathrm{H}_{4}$ : komite audit berpengaruh positif terhadap auditor switching.

\section{METODE}

Metode penelitian yang digunakan dalam studi ini adalah metode kuantitatif. Variabel dependen adalah auditor switching, dan variabel independen terdiri dari opini auditor, ukuran KAP, financial distress, dan komite audit. Hubungan variabel pada penelitian ini terdapat dalam Gambar 1.

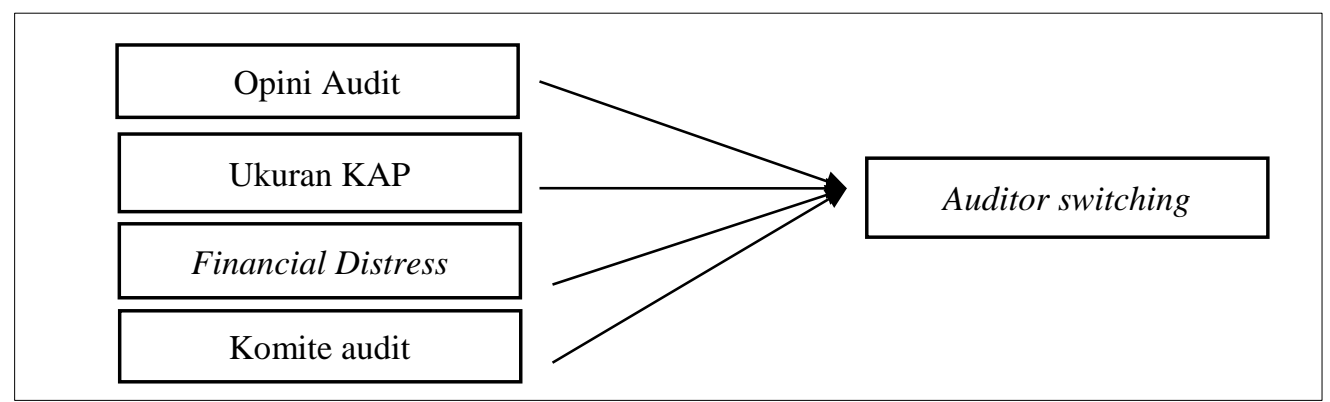

Gambar 1. Desain Penelitian 


\section{Variabel Penelitian}

Auditor switching merupakan variabel dummy. Jika perusahaan klien melakukan auditor switching, diberi nilai 1, sedangkan jika perusahaan klien tidak melakukan auditor switching diberi nilai 0 (Efendy Dan Rahayu, 2015). Opini audit adalah pernyataan auditor terhadap kewajaran laporan keuangan dari entitas yang telah di audit. Kewajaran ini menyangkut materialitas, posisi keuangan, hasil usaha dan arus kas. Variabel opini audit merupakan variabel dummy yang diukur dengan menggunakan satu item pertanyaan. Jika perusahaan klien menerima opini wajar tanpa pengecualian (WTP) maka diberikan nilai 1, dan nilai 0 untuk opini selain WTP (Efendy dan Rahayu, 2015). KAP besar dan KAP kecil memiliki kemampuan dan sumber daya yang sangat berbeda, dan kemungkinan alasan pemutusan perikatan antara auditor dan klien dapat berbeda pula. Variabel yang digunakan merupakan variabel dummy, angka 1 mewakili KAP big four dan angka 0 mewakili KAP non big four (Efendy dan Rahayu, 2015).

Financial distress adalah kondisi perusahaan yang sedang mengalami kesulitan keuangan. Perusahaan yang mengalami kesulitan keuangan akan cenderung mengikat auditor. Financial distress diproksikan dengan rasio debt to asset ratio (DAR). Semakin tinggi DAR maka semakin tinggi risiko kesulitan keuangan yang dialami perusahaan. Rumus yang digunakan untuk menghitung DAR adalah total hutang dibagi total asset dikali $100 \%$. Pengukuran komite audit dalam penelitian ini menggunakan proporsi komite audit. Keanggotaan komite audit di suatu perusahaan dibentuk sesuai dengan ketentuan keanggotaan komite audit. Variabel pergantian komite audit merupakan variabel dummy, jika terjadi pergantian keanggotaan komite audit, maka diberi nilai 1 dan jika tidak terjadi pergantian keanggotaan diberikan nilai 0 (Sulistriani dan Sudarso, 2012).

\section{Sampel}

Populasi dalam penelitian ini adalah seluruh perusahaan yang terdaftar di Bursa Efek Indonesia (BEI). Sampel penelitian yang digunakan adalah perusahaan manufaktur yang terdaftar di BEI dari tahun 2011 sampai 2016 dengan metode simple random sampling sebanyak 50 perusahaan. Simple random sampling ialah pengambilan yang dilakukan secara acak sederhana, sehingga tiap unit penelitian atau satuan elemen dari populasi mempunyai kesempatan yang sama untuk dipilih menjadi sampel. Jumlah sampel yang diteliti adalah 50 perusahaan.

\section{Metode Analisis Data}

Uji asumsi klasik yang digunakan dalam penelitian ini adalah uji multikoleniaritas dan uji autokorelasi. Uji multikoleniaritas digunakan untuk menguji adanya korelasi antar variabel independen. Uji autokorelasi digunakan untuk melihat korelasi antara suatu periode $\mathrm{t}$ dengan periode sebelumnya (t-1). Pengujian autokorelasi dilakukan dengan analisis Run Test. Jika terjadi korelasi maka ada problem autokorelasi. Analisis yang digunakan dalam penelitian ini adalah analisis regresi logistik (logistic regression), yaitu teknik analisis yang digunakan jika variabel dependennya diukur dengan skala nominal (non matrik). Persamaan penelitian dapat dirumuskan sebagai berikut.

Keterangan:

$$
Y=a+b_{1} X_{1}+b_{2} X_{2}+b_{3} X_{3}+b_{4} X_{4}+e i
$$

$\begin{array}{ll}\mathrm{Y} & =\text { Auditor Switching } \\ \mathrm{X}_{1} & =\text { Opini Audit } \\ \mathrm{X}_{2} & =\text { Ukuran KAP } \\ \mathrm{X}_{3} & =\text { Financial Distress } \\ \mathrm{X}_{4} & =\text { Komite Audit } \\ \mathrm{a} & =\text { Konstanta } \\ \mathrm{b}_{1} & =\text { Koefisien regresi variabel independen 1 } \\ \mathrm{b}_{2} & =\text { Koefisien regresi variabel independen 2 } \\ \mathrm{b}_{3} & =\text { Koefisien regresi variabel independen 3 } \\ \mathrm{b}_{4} & =\text { Koefisien regresi variabel independen } 4 \\ \text { ei } & =\text { Variabel lain yang tidak diteliti }\end{array}$




\section{HASIL DAN PEMBAHASAN}

Uji asumsi klasik dilakukan dengan melakukan uji multikoleniaritas dan uji autokorelasi. Uji multikoleniaritas dilakukan dengan menghitung nilai tolerance dan VIF. Nilai tolerance untuk masing-masing variabel yang diuji adalah; opini audit sebesar 0,242, ukuran KAP 0,981, financial distress 0,979 , dan komite audit 0,238 . Berdasarkan nilai tersebut dapat disimpulkan bahwa tidak terdapat multikoleniaritas dalam persamaan karena hasil perhitungan tolerance lebih besar dari 0,10. Nilai VIF adalah; opini audit sebesar 4,140, ukuran KAP 1,019, financial distress 1,022, dan komite audit sebesar 4,194. Keseluruhan nilai VIF kurang dari 10, sehingga dapat disimpulkan bahwa tidak terdapat multikoleniaritas. Hasil analisis run test menunjukkan bahwa nilai asymp.sig (2-tailed) sebesar 0.664. Pada tingkat signifikan 5\% dapat disimpulkan bahwa tidak terjadi autokolerasi.

Beberapa pengujian yang dilakukan adalah pengukuran koefisien determinan $\mathrm{R}^{2}$, uji simultan (uji F), dan uji parsial (uji t). Pengujian koefisien determinan $\mathrm{R}^{2}$ dilakukan untuk mengetahui seberapa besar variabel dependen mampu dijelaskan oleh sebab-sebab lain diluar model. Uji $\mathrm{F}$ dilakukan dengan tujuan untuk menguji pengaruh semua variabel independen terhadap variabel dependen yang diformulasikan dalam model persamaan regresi linear berganda. Melihat signifikansi (a) dengan ketentuan, nilai $p \leq 0,05$. Model persamaan regresinya signifikan pada level alfa sebesar 5\%. Uji t bertujuan untuk menguji signifikansi pengaruh masing-masing variabel independen terhadap variabel dependen yang diformulasikan dalam model. Nilai t dan nilai signifikansi $\mathrm{p} \leq 0,05$.

Nilai nagelkerkr $R$ square sebesar 0,932 atau sebesar 93,2\% yang menunjukkan bahwa kamampuan variabel independen dalam menjelaskan variabel dependen sebesar 93,2\% dan terdapat $100 \%-93,2 \%=6,8 \%$ dijelaskan di luar model. Hasil uji $\mathrm{F}$ menunjukkan bahwa variabel independen mempengaruhi variabel dependen secara simultan signifikan sebesar 0,000 atau $0 \%$. Pengaruh opini audit, ukuran KAP, financial distress, dan komite audit terhadap auditor switching secara simultan berpengaruh signifikan terhadap auditor switching dengan nilai signifikan sebesar $0.000<0,05$. Selanjutnya dilakukan analisis regresi logistik, dengan hasil yang disajikan dalam Tabel 1 berikut.

Tabel 1. Analisis Uji Hipotesis

\begin{tabular}{|c|c|c|c|c|c|c|}
\hline & & B & S.E. & Wald & Df & Sig. \\
\hline \multirow[t]{5}{*}{ Step $1^{\mathrm{a}}$} & $\mathrm{OP}(1)$ & $-1,976$ & 1,404 & 1,982 & 1 &, 159 \\
\hline & UKAP(1) & 8,809 & 1,305 & 45,593 & 1 &, 000 \\
\hline & FD &,- 004 &, 021 & , 044 & 1 &, 833 \\
\hline & $\mathrm{KA}(1)$ & 3,357 & 1,609 & 4,355 & 1 & 037 \\
\hline & Constant & $-5,987$ & 1,582 & 14,326 & 1 & ,000 \\
\hline
\end{tabular}

Berdasarkan hasil analisis yang disajikan dalam Tabel 1 , opini audit menunjukkan nilai signifikan sebesar 0,159 , karena tingkat signifikan $p \geq 0,05$ maka opini audit tidak berpengaruh terhadap auditor switching. Hasil penelitian ini mendukung hasil penelitian sebelumnya dari Efendy dan Rahayu (2015) yang mengatakan bahwa opini audit tidak berpengaruh terhadap auditor switching. Hasil pengujian ini juga memperkuat penelitian Salim dan Rahayu (2014) yang menyatakan bahwa opini audit tidak berpengaruh terhadap auditor switching, namun setelah dimodifikasi dengan opini audit going concern maka berpengaruh terhadap auditor switching, karena perusahaan sangat memerlukan informasi tersebut untuk meningkatkan kepercayaan terhadap klien.

Ukuran KAP berpengaruh terhadap auditor switching dengan nilai signifikan 0,000 maka hipotesis diterima karena $\mathrm{p} \leq 0,05$. Penelitian ini memperkuat penelitian sebelumnya yaitu penelitian Susan dan Trisnawati (2011) yang menyatakan bahwa variabel ukuran KAP memiliki pengaruh terhadap auditor switching. Wea dan Murdiawati (2015) juga mengatakan bahwa ukuran KAP berpengaruh terhadap auditor switching. KAP Big four memiliki independensi yang lebih kuat dan akan lebih bisa menahan tekanan dari manajemen. Penelitian ini tidak konsisten dengan hasil penelitian Wijaya dan Rismani (2015) yang menyatakan bahwa ukuran KAP tidak berpengaruh terhadap auditor switching. Salim dan Rahayu (2014) menyatakan bahwa ukuran 
KAP tidak berpengaruh karena besar atau kecil ukuran KAP tidak menjadi alasan perusahaan melakukan auditor switching, namun hal ini juga didasari karena keterbatasan penelitian dalam periode yang tidak terlalu panjang dan sampel yang terbatas.

Financial distress tidak dapat mempengaruhi perusahaan melakukan perubahan auditor dengan nilai signifikan 0,883 berarti $\mathrm{p} \geq 0,05$ hipotesis ditolak. Kondisi keuangan perushaan merupakan suatu gambaran baik buruknya kinerja perusahaan. Financial distress tidak mampu mempengaruhi auditor switching karena auditor switching tidak selalu berhubungan dengan fee audit yang lebih rendah, bahkan bisa jadi sebaliknya. Penelitian ini memperkuat penelitian sebelumnya dari Wijaya dan Rismani (2015) yang menyatakan bahwa financial distress tidak berpengaruh terhadap auditor switching. Budiono (2015) juga mengatakan bahwa financial distress tidak berpengaruh terhadap auditor switching. Penelitian ini tidak konsisten dengan hasil penelitian sebelumnya dari Salim dan Rahayu (2015) yang menyatakan bahwa financial distress memiliki pengaruh signifikan terhadap auditor switching karena pergantian KAP dapat meningkatkan kualitas pelaporan audit dan membantunya untuk menurunkan fee audit apabila KAP yang dipilih bukan big four namun dengan kualitas audit yang tidak jauh berbeda. Penelitian Wea dan Murdiawati (2015) menyatakan bahwa financial distress memiliki pengaruh terhadap auditor switching.

Komite Audit berpengaruh signifikan terhadap auditor switching, dengan nilai signifikan 0,037. Penelitian ini memperkuat penelitian Ayu dan Sukrapratiwi (2015) yang menyatakan bahwa aktivitas dan pergantian anggota komite audit tidak mampu memoderasi pengaruh penerbitan opini going concern pada auditor switching. Hal ini disebabkan oleh moderasi opini going concern dan keterbatasan penelitian tentang kurangnya objek dan jumlah sampel.

\section{SIMPULAN}

Opini audit tidak berpengaruh terhadap auditor switching. Ukuran KAP berpengaruh positif terhadap auditor switching. Pengaruh financial distress terhadap auditor switching dengan analisis regresi logistik tidak berpengaruh terhadap auditor switching. Penelitian ini bertentangan dengan hasil penelitian sebelumnya yang menyatakan bahwa financial distress memiliki pengaruh signifikan terhadap auditor switching. Komite audit berpengaruh terhadap auditor switching. Penelitian ini tidak konsisten dengan hasil penelitian sebelumnya yang menyatakan bahwa baik aktivitas maupun pergantian anggota komite audit tidak mampu memoderasi pengaruh penerbitan opini going concern pada pergantian KAP.

Keterbatasan dari penelitian ini adalah 1) objek penelitian hanya perusahaan manufaktur yang terdaftar di BEI pada tahun 2011 sampai 2016, 2) penelitian ini hanya menguji pengaruh variabel-variabel opini audit, ukuran KAP, financial distress dan komite audit sementara masih terdapat variabel lain yang mungkin mempengaruhi auditor switching, 3) perusahaan yang hanya berjumlah 50 perusahaan dengan periode penelitian 6 tahun dan jumlah data 300 akan lebih baik jika lebih banyak sampel yang diteliti. Saran dari hasil penelitian ini adalah memperluas sampel penelitian dengan menggunakan seluruh perusahaan yang terdaftar di BEI, menambah tahun penelitian agar periode penelitian lebih panjang dengan hasil yang lebih baik, mempertimbangkan variabel lain yang mempengaruhi auditor switching seperti kepemilikan manajerial, audit fee, opini going concern, dan presentase Return On Assets (ROA), dan penggunaan pengukuran variabel yang berbeda misalnya pada komite audit menggunakan aktivitas komite audit.

\section{DAFTAR RUJUKAN}

Aurora, Frida. 2013. Analisis Faktor - Faktor Yang Mempengaruhi Auditor Switching. Skripsi. Jurusan Akuntansi Fakultas Ekonomi Dan Bisnis Universitas Islam Negeri Syarif Hidayatullah, Jakarta.

Ayu, Ida dan Sukrapratiwi. 2015. Pengaruh Komite Audit Dalam Penerbitan Opini Going Concern Pada Pergantian Auditor. E-Jurnal Akuntansi Universitas Udayana 12. 3 Hal 671-685.

Budiono, Eddy. 2015. Pengaruh Financial Distress, Pertumbuhan Perusahaan, Perubahan ROA, dan Ukuran Perusahaan Klien Terhadap Auditor Switching. E-Proceeding Of Management: Vol. 2, No.1. 
Efendy, dan Rahayu. 2015. Analisis Pengaruh Opini Audit, Ukuran Kantor Akuntan Publik, Ukuran Perusahaan Klien, dan Kepemilikan Manajerial Terhadap Auditor Switching. Jurnal Akuntansi Dan Keuangan Vol. 4 No. 1

Jensen, Michael C \& Meckling W.H. 1976. Theory of The Firm: Managerial Behavior, Agency Cost and Ownership Structure. Journal of Financial Economics 3. hal 305- 360.

Kementerian Keuangan RI. Peraturan Menteri Keuangan Republik Indonesia Nomor 17/PM K.01/2008 Tentang Jasa Akuntan Publik.

Pratiwi, Latrini. 2015. Karakteristik Komite Audit Memoderasi Pengaruh Penerbitan Opini Going Concern pada Pergantian Auditor. E-Jurnal Akuntansi Universitas Udayana 12.3 (2015): 671-685, Bali.

Salim, Apriyeni dan Rahayu, Sri. 2014. Pengaruh Opini Audit, Ukuran KAP, Pergantian Manajemen, dan Financial Distress Terhadap Auditor Switching. E-Proceding Of Management Vol.1, No.3

Sulistriarini dan Sudarso. 2012. Analisis Faktor-faktor Pergantian Kantor Akuntan Publik. Diponegoro Journal Of Accountings. Volume 1, Nomor 2, Halaman 1-12

Susan dan Trisnawati, Estralita. 2011. Faktor-faktor yang Mempengaruhi Perusahaan Melakukan Auditor Switching. Jurnal Bisnis Dan Akuntansi. Vol. 13, No. 2, Agustus 2011.

Wea, Alexandrus dan Murdianti, Dewi. 2015. Faktor yang Mempengaruhi Perusahaan Melakukan Auditor Switching secara Voluntary pada Perusahaan Manufaktur di BEI. Jurnal Bisnis Ekonomi vol. 22, no.2

Wijaya dan Rasmini. 2015. Pengaruh Fee Audit, Opini Going Goncern, Financial Distress, Ukuran KAP pada Pergantian Auditor. FE Universitas Udayana. E-Jurnal Akuntansi Udayana. 11. 